\title{
KARAKTERISTIK TES LITERASI MEMBACA PADA PROGRAMME FOR INTERNATIONAL STUDENT ASESSMENT (PISA)
}

\author{
Titik Harsiati*, Endah Tri Priyatni \\ Universitas Negeri Malang
}

\section{A R T I K E L}

Kata Kunci:

Karakteristik

Tes

Literasi membaca

PISA

\begin{abstract}
A B S T R A K
Penelitian ini bertujuan mendeskripsikan karakteristik tes literasi membaca pada Programme for International Student Asessment (PISA), yang difokuskan pada karakteristik tingkat berpikir dan kompetensi membaca yang diukur, jenis stimulus yang digunakan, ragam tes, dan karakteristik pertanyaan. Penelitian ini adalah penelitian kualitatif dengan teknik analisis isi. Sumber data penelitian adalah soal-soal literasi membaca PISA dari tahun 2000-2009. Hasil analisis menunjukkan bahwa tes literasi membaca PISA didominasi keterampilan berpikir tingkat tinggi yang berupa kemampuan interpretasi, refleksi, dan evaluasi. Jenis kompetensi membaca yang diukur adalah: kemampuan mengungkapkan kembali informasi, mengembangkan interpretasi dan mengintegrasikan, dan merefleksikan dan mengevaluasi teks. Stimulus berupa teks panjang dengan jumlah kata berkisar 135-630, kalimat pertanyaan bersifat kompleks dan ragam tes yang digunakan adalah pilihan ganda, pilihan ganda kompleks, jawaban singkat, esai tertutup, dan esai terbuka.
\end{abstract}

(c) 2017 BIBLIOTIKA Journal. All rights reserved

\section{PENDAHULUAN}

Informasi yang akurat mengenai mutu pendidikan di Indonesia dalam mempersiapkan peserta didik untuk menjalankan kehidupan bermasyarakat di era global sangat diperlukan. Selain itu, benchmarking mutu pendidikan antarnegara menjadi bagian penting dalam menentukan arah pendidikan suatu negara. Sebagai salah satu upaya benchmarking pencapaian program pendidikan nasional, Indonesia berpartisipasi dalam studi internasional Programme for International Student Assessment (PISA). PISA merupakan studi yang dikoordinasikan oleh negaranegara OECD (Organisation for Economic Cooperation and Development). Studi PISA bertujuan melihat efektivitas sistem pendidikan dalam perspektif internasional dengan berfokus pada hasil asesmen sains, matematika, dan literasi membaca.

Pengertian literasi membaca berkembang selaras dengan perkembangan makna literasi. Literasi pada awal kemunculannya dimaknai sebagai keberaksaraan atau melek aksara yang fokus utamanya pada kemampuan membaca dan menulis, dua keterampilan yang menjadi dasar untuk melek dalam berbagai hal (Kalantzis, 2015). Pada perkembangan berikutnya, literasi dimaknai sebagai melek membaca, menulis, dan numerik, tiga keterampilan dasar untuk kecakapan hidup (Kalantzis, 2015). Kemampuan literasi membaca berkaitan dengan kemampuan memahami secara kritis-kreatif berbagai bentuk wacana tulis yang ada dalam komunikasi nyata (Hayat, 2006). Pada era perkembangan informasi teknologi dan globalisasi, literasi membaca dimaknai secara luas. literasi membaca mencakup makna melek teknologi, berpikiran kritis, peka terhadap lingkungan sekitar, serta mampu mengaplikasikan apa yang dibaca.

Literasi membaca merupakan kemampuan seseorang dalam memahami, menggunakan dan merefleksikan bacaan tertulis untuk mencapai tujuan sesuai keperluan, mengembangkan pengetahuan dan potensi, serta berpartisipasi dalam masyarakat. Literasi membaca diukur dalam hubungannya dengan: (1) format bacaan: narasi, eksposisi, dan argumentasi, formulir, tabel, atau bagan, (2) tingkat berpikir dalam proses membaca mencakup kegiatan mencari informasi, membentuk pemahaman yang luas dari teks, menginterpretasikan, merefleksi/ mengevaluasi

\footnotetext{
${ }^{*}$ Corresponding author.

E-mail addresses: titik.harsiati.fs@um.ac.id (Titik Harsiati), endah.tri.fs@um.ac.id (Endah Tri Priyatni)
} 
(konten, bentuk, dan cirinya), dan (3) konteks isi kutipan dan tujuan pemilihan kutipan.Literasi membaca dilihat dari kemampuan siswa menggunakan teks tulis untuk tujuan-tujuan yang dituntut secara sosial dan berguna bagi individu untuk mengembangkan pengetahuan/potensinya. Dalam literasi membaca, membaca bukan decoding sederhana tetapi memadukan pemahaman dan penggunaan informasi tulis untuk tujuan-tujuan fungsional.

Literasi membaca mencakup kemampuan kognitif yang lebih luas daripada pengodean dasar melalui pengetahuan kata per kata, tata bahasa, linguistik dan struktur teks. Literasi membaca merupakan kemampuan metakognitif yang berisi kesadaran dan kemampuan menggunakan berbagai strategi yang sesuai ketika memproses teks. PISA mendefinisikan literasi membaca sebagai sebuah pemahaman, menggunakan dan merefleksikan tek tertulis untuk mencapai tujuan, memperoleh pengetahuan, mengembangkan potensi dan berpartisipasi dalam masyarakat (OECD, 2006).

Kemampuan literasi membaca mutakhir berkaitan erat dengan kemampuan berpikir, kemampuan bernalar, dan kreativitas yang diperlukan seseorang untuk hidup di zaman informasi. Pada zaman serba modern, seorang dapat dikatakan memiliki kemampuan literasi jika ia sudah dapat memahami sesuatu karena membaca dan melakukan sesuatu berdasarkan pemahaman bacaannya (Hirai, 2009). Kemampuan literasi membaca adalah kemampuan untuk memanfaatkan wacana tulis dengan memahami ciri-ciri dan kunci-kunci penanda makna untuk memprediksi, menginterpretasi, dan merekonfirmasi makna secara tepat.

Selama 12 tahun mengikuti PISA, prestasi Indonesia masih di bawah rata-rata skor literasi membaca internasional. Pada tahun 2000 rata-rata skor literasi membaca siswa Indonesia sebesar 371 (OECD, 2000). Pada tahun 2003 rata-rata skor literasi membaca siswa Indonesia sebesar 382 (OECD, 2003). Pada tahun 2006 rata-rata skor literasi membaca siswa Indonesia sebesar 393 (OECD, 2006). Pada tahun 2009 rata-rata skor literasi membaca siswa Indonesia sebesar 402 (OECD, 2009). Padahal rata-rata skor minimal literasi internasional seharusnya sebesar 500 (OECD, 2009). Kemampuan literasi membaca siswa Indonesia berada pada level 2 dari 6 level yang ada. Karakteristik level 2 adalah dapat menemukan satu atau dua informasi yang dibutuhkan untuk membuat inferensi atau menghadapi beberapa kondisi. Siswa juga mampu menentukan ide pokok, memahami hubungan, mengkontruksi makna untuk inferensi.

Berdasarkan data kondisi kemampuan literasi membaca siswa Indonesia yang masih berada jauh di level bawah tersebut, dilakukan penelitian terhadap karakteristik tes literasi membaca pada program internasional PISA dari tahun 2000-2009. Dengan penelitian ini diperoleh gambaran utuh karakteristik tes literasi membaca PISA.

Studi PISA dilaksanakan setiap tiga tahun dengan penekanan yang berbeda-beda. Siklus pertama tahun 2000, 2003, dan 2006, siklus kedua tahun 2009, 2012, dan 2015. Urutan penekanan domain pada setiap siklus adalah membaca, matematika, dan sains. Indonesia telah mengikuti survei PISA ini mulai tahun 2000. Jumlah negara yang berpartisipasi pada studi PISA tahun 2000 diikuti oleh 43 negara, tahun 2003 sebanyak 41 negara, tahun 2006 sebanyak 57 negara, dan tahun 2009 diikuti oleh 65 negara.

Pada PISA literasi membaca mencakup pemahaman/proses berpikir tingkat tinggi yang menuntut pembaca memberikan reaksi kritis-kreatif terhadap bacaan dalam menemukan signifikasi, nilai, fungsi, dan hubungan isi bacaan itu dengan suatu masalah kehidupan yang lebih luas serta dampak dari masalah yang dipaparkan pengarang berpikir kritis-kreatif. Pembaca menggunakan atau mengolah berbagai jenis wacana yang ada dalam komunikasi nyata secara kritis-kreatif. Alderson (2000) menyatakan bahwa literasi membaca mencakup proses dan produk. Membaca sebagai proses mekanistis digolongkan sebagai membaca tingkat rendah. Membaca bukan hanya membaca informasi secara literal, tetapi membaca secara interaktif untuk mendapatkan pemahaman secara kritis-kreatif terhadap teks.

Teks secara garis besar dikelompokkan dua bagian yaitu teks kontinyus dan nonkontinyus. Teks berkesinambungan (kontinyus) mencakup jenis teks deskripsi (impresionistik, teknis), narasi (paparan naratif, laporan, berita), eksposisi (esai eksposisi, definisi, penjelasan, ringkasan, notulen, teks interpretasi), argumentasi (komentar, argumentasi ilmiah), instruksi (arahan, aturan). Teks nonkontinyus: berupa daftar sederhana, daftar campuran, daftar kolom, daftar jaringan, daftar kombinasi), dengan format (form, lembar info, vucer, sertfikat, iklan, bagan/ grafik, tabel dan matrik, daftar sesuatu, peta).

Dengan telaah karakteristik tes literasi PISA ini diharapkan dapat memberikan masukan dalam upaya meningkatkan kemampuan literasi membaca siswa Indonesia di masa mendatang. Lembaga terkait dapat menggunakan hasil telaah ini untuk mengembangkan bahan ajar, metode, dan sistem penilaian membaca yang sesuai agar dapat menyiapkan pengetahuan dan keterampilan siswa usia 15 tahun (akhir SMP).

Tujuan penelitian ini adalah mendeskripsikan karakteristik tes literasi membaca pada Programme for International Student Asessment (PISA), yang difokuskan pada jenis keterampilan berpikir dan jenis kompetensi membaca yang diukur, jenis stimulus yang digunakan, ragam tes, dan karakteristik pertanyaan soal literasi membaca dari tahun 2000-2009.

\section{METODE PENELITIAN}

Penelitian ini menggunakan metode kualitatif karena penelitian ini menghasilkan data deskriptif berupa katakata tertulis atau lisan dari objek yang diamati (Seviula, 1991). Sumber data adalah soal literasi membaca PISA pada tahun 2000, 2003, 2006, dan 2009. Teknik analisis data menggunakan teknik analisis isi. Dengan teknik analisis isi dapat disimpulkan karakter inferensial dari pengkodean unit-unit tekstual ke dalam kategori-kategori konseptual dan inferensi-inferensi dengan mengidentifikasi secara sistematik dan objektif ciri-ciri khusus sebuah fenomena tekstual (Krippendorff, 1993).

\section{2 | BIBLIOTIKA : Jurnal Kajian Perpustakaan dan Informasi}


Wujud data dalam penelitian ini adalah paparan: (1) karakteristik tingkat berpikir dan kompetensi membaca yang diukur pada soal literasi membaca PISA (2) jenis stimulus yang digunakan untuk mengembangkan tes, (3) ragam tes yang digunakan pada tes literasi membaca PISA, dan (4) karakteristik pertanyaan pada tes literasi membaca PISA.

\section{HASIL PENELITIAN}

Karakteristik Tingkat Berpikir dan Kompetensi Membaca yang Diukur

Temuan penelitian menunjukkan bahwa berpikir tingkat tinggi mendominasi keseluruhan soal membaca PISA dari tahun 2000 sampai dengan 2009. Kemampuan berpikir tingkat tinggi mencakup kemampuan mengembangkan interpretasi, kemampuan merefleksi, dan kemampuan mengevaluasi teks. Kompetensi membaca yang diukur, dapat dikategorikan menjadi tiga jenis, yaitu: (1) kemampuan mengungkapkan kembali informasi (retrieving information), (2) mengembangkan menginterpretasi, dan (3) kemampuan merefleksikan dan mengevaluasi teks. Di bawah ini dicontohkan soal mengungkapkan kembali informasi, mengintegrasikan/menginterpretasi, serta merefleksi dan mengevaluasi.

\section{Contoh soal}

\section{SI KIKIR DAN EMASNYA}

Seorang yang kikir menjual seluruh hartanya dan membeli segumpal emas yang dikuburnya di dalam sebuah lubang di samping sebuah dinding tua. Dia kemudian mengunjungi simpanannya itu setiap hari. Salah seorang anak buahnya memperhatikan hal ini dan memutuskan untuk mengintai gerak gerik si kikir. Anak buahnya ini kemudian mengetahui rahasia harta yang tersembunyi tersebut, dan mulai menggali, dan menemukan segumpal emas, dan dicurinya.

Si kikir, pada kunjungan berikutnya, menemukan lubang yang sudah kosong dan mulai menarik-narik rambutnya dan meraung-meraung sejadi-jadinya. Seorang tetangga, yang melihat kejadian itu dan mengetahui apa penyebabnya, kemudian berkata, "Berdoalah dan jangan bersedih, ambillah segumpal batu, dan letakkan di dalam lubang itu, dan bayangkan seolah-olah emas itu masih berada di sana. Bagi kamu hal itu akan sama saja, karena sewaktu emas itu berada di sana, kamu tidak memilikinya, karena kamu sedikit pun tidak menggunakannya."

\section{Gunakan cerita rakyat "Si Kikir dan Emasnya" untuk menjawab pertanyaan berikut!}

TIPE PERTANYAAN 1: Menemukan Kembali Informasi dari Teks

\section{Pertanyaan 1: SI KIKIR}

Bacalah pernyataan berikut dan berilah nomor sesuai dengan urutan kejadian di dalam bacaan.

1. Si kikir memutuskan untuk menggunakan seluruh uangnya untuk membeli segumpal emas.

2. Seseorang mencuri emas si kikir.

3. Si kikir menggali lubang dan menyembunyikan hartanya di sana.

4. Tetangga si kikir menyuruhnya untuk menggantikan emas itu dengan sebuah batu. 
TIPE PERTANYAAN 2: Mengintegrasikan dan menginterpretasikan

pembaca dituntut mengembangkan interpretasi dengan mengintegrasikan berbagai pengetahuan dan menghubungkan rincian cerita dengan ide utama

Pertanyaan 2: SI KIKIR

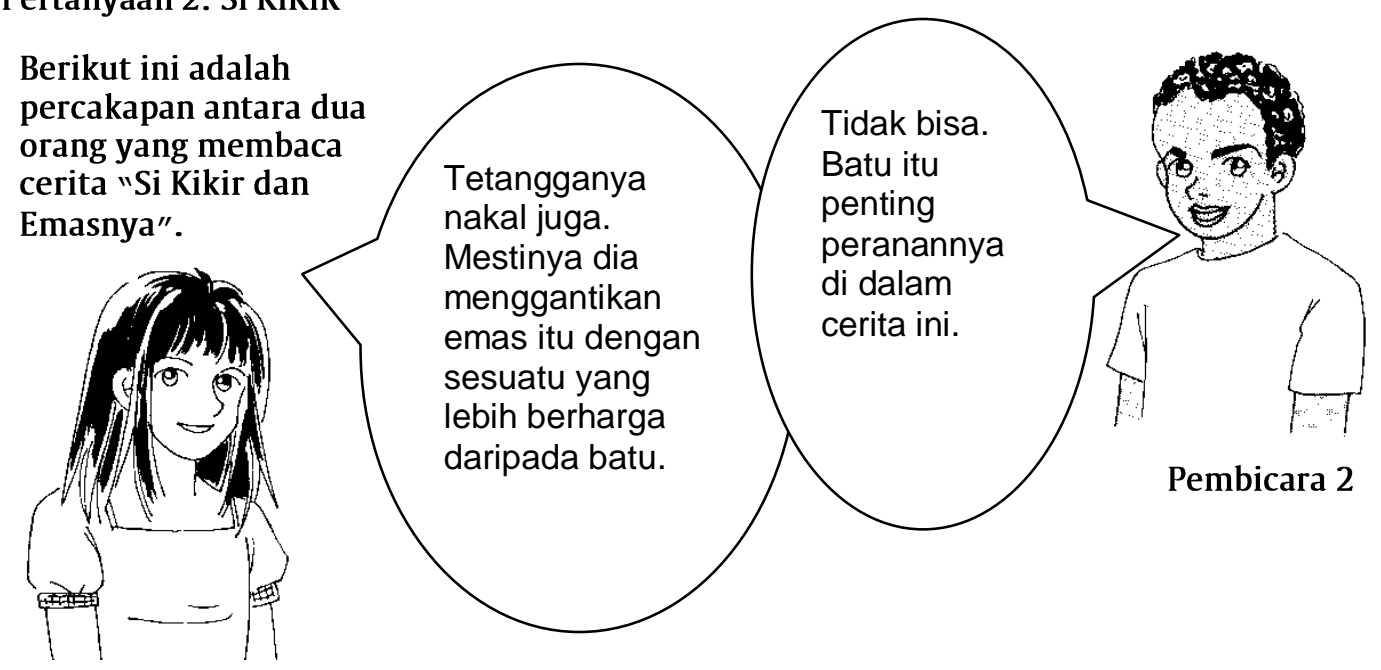

Pembicara 1

Apa yang dapat dikatakan Pembicara 2 untuk mendukung pendapatnya?

Pertanyaan 3: SI KIKIR R433Q06-0 19

Mengapa si kikir mengubur emasnya?

\section{Pertanyaan 4: SI KIKIR R433Q02}

Apa pesan utama cerita ini?
A Jangan menyimpan kekayaan yang mudah dicuri.
B Memercayai orang lain adalah suatu kesalahan.
C Tidak menggunakan apa yang dimiliki sama dengan tidak memilikinya.
D Jangan menangisi sesuatu yang tidak bisa diubah.

TIPE PERTANYAAN 3: Merefleksikan dan mengevaluasi isi bacaan

Pembaca membuat hipotesis alasan perbuatan pelaku cerita dengan menggabungkan informasi sebelumnya dengan informasi pada bacaan serta informasi di luar teks.

\section{Pertanyaan 5: SI KIKIR}

Apakah pesan cerita Si Kikir dan Emasnya, masih relevan untuk kondisi masyarakat saat ini? Berikan alasan untuk jawabanmu!

\section{Pertanyaan 6: SI KIKIR}

Apakah saat ini masih ada orang-orang yang memiliki perilaku seperti Si Kikir? Berikan alasan dan contoh jika jawabanmu ADA! Berikan alasan jika jawabanmu TIDAK ADA!

\section{Jenis Stimulus yang Digunakan untuk Mengembangkan Tes Literasi Membaca}

PISA bertujuan mengukur sejauh mana pendidikan dasar di suatu negara mampu menyiapkan siswanya untuk menghadapi dunia nyata, menggapai pengetahuan yang lebih tinggi, bersosialisasi di kancah global, dan memenuhi kebutuhan dasar/keterampilan hidup siswa. Dengan tujuan tersebut, stimulus yang digunakan untuk mengembangkan 
tes memiliki karakteristik isi yang khas. Karakteristik stimulus tes literasi membaca PISA dapat dilihat pada tabel berikut.

Tabel 1: Jenis Stimulus Tes PISA

\begin{tabular}{|c|c|c|}
\hline Konteks & Tema/isi kutipan & Tujuan \\
\hline $\begin{array}{l}\text { Konteks pendidikan, } \\
\text { pekerjaan, personal, } \\
\text { masyarakat pada wacana } \\
\text { kontinyus (paparan } \\
\text { paragraf) }\end{array}$ & $\begin{array}{l}\text { Cara mengikuti pertukaran pelajar, } \\
\text { keamanan bahaya penggunaan HP, } \\
\text { penggunaan, cara dan rasional menggosok } \\
\text { gigi yang benar, memilih baju yang tepat, } \\
\text { memilih sepatu yang tepat, cara dan } \\
\text { rasional memilih makanan di supermarket, } \\
\text { cara menghindari iklan obral yang } \\
\text { berlebihan, memilih nilai-nilai moral untuk } \\
\text { mencintai profesi, memilih nilai-nilai moral } \\
\text { untuk menjalani hidup dengan bahagia }\end{array}$ & $\begin{array}{l}\text { Meningkatkan keterampilan hidup } \\
\text { dalam mengakses dan memanfaatkan } \\
\text { informasi berupa wacana untuk } \\
\text { menjalani kehidupan dalam konteks } \\
\text { pendidikan, pekerjaan, keselamatan, } \\
\text { dan keamanan diri }\end{array}$ \\
\hline $\begin{array}{l}\text { Konteks pendidikan, } \\
\text { pekerjaan, personal, } \\
\text { masyarakat pada wacana } \\
\text { nonkontinyus (berupa } \\
\text { tabel, grafik, bagan, denah } \\
\text { formulir) }\end{array}$ & $\begin{array}{l}\text { Orientasi denah kendaraan umum, denah } \\
\text { perpustakaan, cara mencapai suatu tempat } \\
\text { penting, cara mengisi tabel/ angket pada } \\
\text { survei, memahami grafik hasil survei } \\
\text { tentang kebutuhan hidup, memahami dan } \\
\text { mengisi formulir }\end{array}$ & $\begin{array}{l}\text { Meningkatkan keteram-pilan hidup } \\
\text { mengakses dan memanfaatkan in- } \\
\text { formasi berupa denah, peta, tabel, } \\
\text { formulir dan grafik untuk menjalani } \\
\text { kehidupan dalam kon-teks pendidikan, } \\
\text { peker-jaan, keselamatan dan keamanan } \\
\text { diri }\end{array}$ \\
\hline
\end{tabular}

Dari tabel di atas dapat disimpulkan bahwa stimulus yang digunakan untuk mengembangkan tes literasi membaca adalah teks dengan topik: pendidikan, pekerjaan, personal, dan masyarakat. Isi kutipan pada soal membaca PISA dipilih dengan tujuan untuk meningkatkan keterampilan hidup dalam mengakses dan memanfaatkan informasi berupa wacana untuk menjalani kehidupan dalam masyarakat, pendidikan, pekerjaan, dan personal. Sebaran persentase jenis stimulus pada tes literasi membaca PISA dipaparkan pada Tabel 2 berikut.

Tabel 2: Distribusi Stimulus Tes Literasi Membaca PISA

\begin{tabular}{lccccccc}
\hline \multicolumn{1}{c}{ Jenis Stimulus } & MC & $\begin{array}{c}\text { MC } \\
\text { kompleks }\end{array}$ & $\begin{array}{c}\text { CR } \\
\text { Tertutup }\end{array}$ & $\begin{array}{c}\text { CR } \\
\text { Terbuka }\end{array}$ & $\begin{array}{c}\text { Jawaban } \\
\text { singkat }\end{array}$ & Total & Persentase \\
\hline Pendidikan & 22 & 4 & 1 & 4 & 5 & 36 & $27,27 \%$ \\
\hline Pekerjaan & 4 & 1 & 4 & 9 & 4 & 22 & $16,66 \%$ \\
\hline Personal & 10 & & 3 & 10 & 3 & 26 & $19,69 \%$ \\
\hline Masyarakat & 18 & 1 & 7 & 17 & 5 & 48 & $36,36 \%$ \\
\hline Total & 54 & 6 & 15 & 40 & 17 & 132 & $100 \%$ \\
\hline
\end{tabular}

Dari tabel di atas dapat disimpulkan bahwa tes literasi membaca PISA sebagian besar menggunakan stimulus dengan topik masyarakat (36,36\%), pendidikan (27,27\%), personal (19,69\%), dan pekerjaan (16, 66\%).

\section{Ragam Tes Literasi Membaca PISA}

Ragam tes yang digunakan pada soal membaca PISA adalah pilihan ganda, pilihan ganda kompleks, jawaban singkat, esai tertutup, dan esai terbuka. Ragam tes tersebut disajikan bervariasi berdasarkan sebuah teks yang mendahuluinya. Sebuah teks dikembangkan menjadi tes pilihan ganda, pilihan ganda kompleks, tes esai terbuka, dan esai tertutup. Soal esai dan objektif tidak dikelompokkan sendiri tetapi berselang-seling digunakan pada pada semua teks. Distribusi ragam tes membaca berdasarkan tingkat kompetensi membaca yang diukur dapat dilihat pada Tabel 3 berikut.

Tabel 3: Distribusi Ragam Tes Membaca Berdasarkan Tingkat Kompetensi

\begin{tabular}{lcccc}
\hline Format butir soal & $\begin{array}{c}\text { Jumlah } \\
\text { Butir }\end{array}$ & $\begin{array}{c}\text { Menggali } \\
\text { informasi }\end{array}$ & $\begin{array}{c}\text { Mengintegrasikan } \\
\text { dan } \\
\text { menginterpretasi } \\
\text { bacaan }\end{array}$ & $\begin{array}{c}\text { Merefleksi } \\
\text { dan } \\
\text { mengevaluasi }\end{array}$ \\
\hline Pilihan Ganda & 9 & 0 & 9 & 0 \\
\hline Pilihan Ganda Kompleks & 1 & 1 & 0 & 0 \\
\hline Respon tertutup & 7 & 6 & 1 & 0 \\
\hline Esai terbuka & 14 & 3 & 4 & 7 \\
\hline Jumlah & 31 & 10 & 14 & 7 \\
\hline Persentasi & $100 \%$ & $32,25 \%$ & $45,16 \%$ & $22,58 \%$ \\
\hline
\end{tabular}


KEAMANAN TELEPON GENGGAM (HP)

\section{Apakah HP berbahaya?}

\section{Ya}

1. Gelombang radio yang dikeluarkan HP dapat meningkatkan panas sel tubuh, yang menimbulkan dampak yang membahayakan.

2. Medan magnet yang ditimbulkan HP dapat memengaruhi cara kerja sel-sel tubuh.

Berbagai laporan yang saling bertentangan tentang resiko kesehatan HP muncul pada akhir tahun 1990an.

\section{Ide Utama \\ Milyaran rupiah telah dikeluarkan dalam penelitian ilmiah untuk meneliti dampak HP.} berdekatan dengan telinga yang digunakan untuk menelepon 2,5 kali lipat lebih besar daripada bukan pengguna HP.

5. Organisasi Internasional untuk Penelitian di Bidang Kanker menemukan hubungan antara

\section{Tidak}

Gelombang radio tidak cukup kuat untuk dapat menyebabkan peningkatan suhu tubuh yang membahayakan.

Medan magnet kekuatannya sangat kecil, sehingga tidak mungkin dapat memengaruhi sel-sel di dalam tubuh kita.

Pengaruh-pengaruh seperti ini belum pernah diobservasi secara teliti dan mungkin saja hal ini disebabkan oleh faktor-faktor lain dalam gaya hidup modern.

Para peneliti mengakui bahwa meningkatnya kemungkinan terkena kanker ini belum tentu berhubungan dengan penggunaan HP. penyakit kanker pada anak-anak dengan kabel tegangan tinggi listrik. Seperti halnya HP, kabel tegangan tinggi listrik juga mengeluarkan radiasi.

6. Gelombang frekuensi radio sama dengan gelombang dari HP mengubah gen cacing tambang.
Cacing tambang bukanlah manusia, sehingga tidak ada jaminan bahwa sel otak kita akan bereaksi dengan cara yang sama. 
Jika kamu menggunakan HP ...

\begin{tabular}{|l|}
\hline Ide Utama \\
Mengingat banyaknya \\
pengguna HP, efek sekecil \\
apapun yang terjadi pada \\
kesehatan dapat memiliki \\
implikasi yang luas terhadap \\
kesehatan masyarakat. \\
\hline
\end{tabular}

\section{Ide Utama}

Pada tahun 2000, Laporan

Stewart (sebuah laporan Inggris) menemukan tidak adanya persoalan kesehatan yang disebabkan oleh HP, tetapi laporan itu meminta untuk tetap berhati-hati, terutama bagi para remaja, sampai penelitian lebih lanjut dilakukan. Laporan selanjutnya pada tahun 2004 mendukung hasil penelitian terdahulu.

\section{Harus \\ Jangan}

Selalu berbicara sesingkat mungkin.

Jangan menggunakan HP bila sinyalnya lemah, karena dalam kondisi ini HP memerlukan energi yang lebih besar untuk bisa berkomunikasi dengan pemancarnya, sehingga emisi gelombang radio yang dikeluarkan lebih besar.

Bila dalam keadaan siap pakai jauhkan posisi HP dari tubuh kamu.

Jangan membeli HP dengan angka "SAR" ${ }^{\dagger}$ yang tinggi. Angka ini berarti HP itu mengeluarkan radiasi yang lebih banyak.

Belilah HP dengan "waktu bicara" yang lama. Hal ini lebih efisien, dan memiliki emisi yang lebih rendah.
Jangan membeli aksesori pelindung bila alat itu belum diuji keamanannya oleh pihak berwenang.

\section{Pertanyaan 1: KEAMANAN HP}

\section{Lihat Tabel Apakah HP berbahaya?}

Apa maksud pernyataan di dalam kolom Tidak?

A Untuk menggambarkan keuntungan menggunakan HP.

B Untuk menggambarkan kerugian menggunakan HP.

C Untuk menjelaskan mengapa HP berbahaya.

D Untuk menentang pernyataan bahwa HP berbahaya.

\section{TIPE PERTANYAAN DAN BENTUK TES}

Bentuk tes pilihan ganda dengan tujuan mengukur kemampuan merefleksikan dan mengevaluasi bacaan serta mengenal hubungan antara pernyataan yang diberikan di luar isi bacaan yang ada di dalam tabel dengan pernyataan yang ada di dalam tabel.

\footnotetext{
${ }^{\dagger}$ SAR (specific absorption rate) adalah suatu ukuran yang menunjukkan seberapa besar radiasi yang diserap oleh sel tubuh manusia sewaktu menggunakan HP.
}

\section{7 | BIBLIOTIKA : Jurnal Kajian Perpustakaan dan Informasi}


Perhatikan poin 3 pada kolom Tidak pada tabel. Dalam konteks ini, kira-kira apa yang menjadi salah satu faktor dari "faktor-faktor lain" tersebut? Berikan alasan untuk jawabanmu.

TIPE PERTANYAAN DAN BENTUK TES

Bentuk tes esai terbuka mengukur kemampuan merefleksikan dan mengevaluasi

\section{Pertanyaan 3: KEAMANAN HP R414Q05}

Perhatikan pernyataan berikut ini: "Hasil penelitian dari satu situasi tidak selalu berlaku pada situasi yang berbeda." Coba tunjukkan apakah masing-masing pernyataan pada kolom Tidak di bawah ini merupakan contoh yang tepat untuk pernyataan di atas atau tidak.

Jawaban untuk tugas pertama diberikan di bawah ini sebagai contoh.

\begin{tabular}{|c|l|c|c|}
\hline \multicolumn{1}{|c|}{ Tidak } & $\begin{array}{c}\text { "Hasil penelitian dari satu situasi } \\
\text { tidak selalu berlaku pada situasi } \\
\text { yang berbeda." }\end{array}$ \\
\hline 1. & $\begin{array}{l}\text { Gelombang radio tidak cukup kuat untuk dapat } \\
\text { menyebabkan peningkatan suhu tubuh yang } \\
\text { membahayakan. }\end{array}$ & $\begin{array}{c}\text { Merupakan } \\
\text { contoh }\end{array}$ & $\begin{array}{c}\text { Tidak } \\
\text { merupakan } \\
\text { contoh }\end{array}$ \\
\hline 2. & $\begin{array}{l}\text { Para peneliti mengakui bahwa meningkatnya } \\
\text { kemungkinan terkena kanker ini belum tentu } \\
\text { berhubungan dengan penggunaan HP. }\end{array}$ & $\begin{array}{c}\text { Merupakan } \\
\text { contoh }\end{array}$ & $\begin{array}{c}\text { Tidak } \\
\text { merupakan } \\
\text { contoh }\end{array}$ \\
\hline 3. & $\begin{array}{l}\text { Radiasi yang dikeluarkan oleh kabel tegangan } \\
\text { tinggi listrik adalah jenis radiasi yang berbeda, } \\
\text { dengan energi yang lebih besar daripada yang } \\
\text { dikeluarkan oleh HP. }\end{array}$ & $\begin{array}{c}\text { Merupakan } \\
\text { contoh } \\
\text { Tidak } \\
\text { merupakan } \\
\text { contoh }\end{array}$ \\
\hline 4. & $\begin{array}{l}\text { Cacing tambang bukanlah manusia, sehingga } \\
\text { tidak ada jaminan bahwa sel otak kita akan } \\
\text { bereaksi dengan cara yang sama. }\end{array}$ & $\begin{array}{c}\text { Merupakan } \\
\text { contoh }\end{array}$ & $\begin{array}{c}\text { Tidak } \\
\text { merupakan } \\
\text { contoh }\end{array}$ \\
\hline
\end{tabular}

\section{TIPE PERTANYAAN DAN BENTUK TES}

Bentuk tes pilihan ganda kompleks dengan mengukur kemampuan merfleksikan dan mengevaluasi kasus merupakan contoh terapan dari isi bacaan atau bukan contoh.

\section{Pertanyaan 4: KEAMANAN HP R414Q09}

Perhatikan tabel dengan judul Jika kamu menggunakan HP ...

Di antara pernyataan berikut, yang manakah yang merupakan dasar ide yang terdapat pada tabel tersebut?

A Tidak ada bahaya yang ditimbulkan oleh penggunaan HP.

B Terdapat bukti yang menunjukkan adanya bahaya menggunakan HP.

C Mungkin ada dan mungkin juga tidak ada bahaya menggunakan HP, tetapi ada baiknya untuk tetap berhati-hati.

D Mungkin ada dan mungkin juga tidak ada bahaya menggunakan HP, tetapi sebaiknya jangan memakai HP dulu sebelum mengetahui secara yakin.

E Pernyataan yang ada pada kolom Harus adalah bagi kelompok orang yang menganggap serius bahaya HP, dan pernyataan pada kolom Jangan adalah bagi kelompok lainnya.

\section{TIPE PERTANYAAN DAN BENTUK TES}

Bentuk tes pilihan ganda dengan mengukur kemampuan menginterpretasi dan mengintegrasikan secara luas. 


\section{Karakteristik Pertanyaan Tes Literasi Membaca PISA}

Tes membaca PISA menggunakan wacana dengan kalimat-kalimat kompleks. Jumlah kata berkisar 135 sampai 610 kata. Pada wacana nonkontinyus (tabel, diagram, grafik) cenderung menggunakan beberapa variabel dan simbol yang rumit. Peta/denah/tabel atau grafik cenderung bersifat kompleks dan berkaitan dengan bagian yang lain. Berikut contoh penggunaan wacana yang berupa tabel rumit.

\section{DANAU CHAD}

Gambar 1 menunjukkan kedalaman yang berubah-ubah dari Danau Chad di Gurun Sahara, Afrika Utara. Danau Chad menghilang sama sekali pada kira-kira 20.000 sebelum Masehi, selama zaman Es. Pada kira-kira 11.000 SM danau itu kembali muncul. Sekarang kedalamannya kira-kira sama dengan kedalaman pada tahun $1000 \mathrm{M}$.

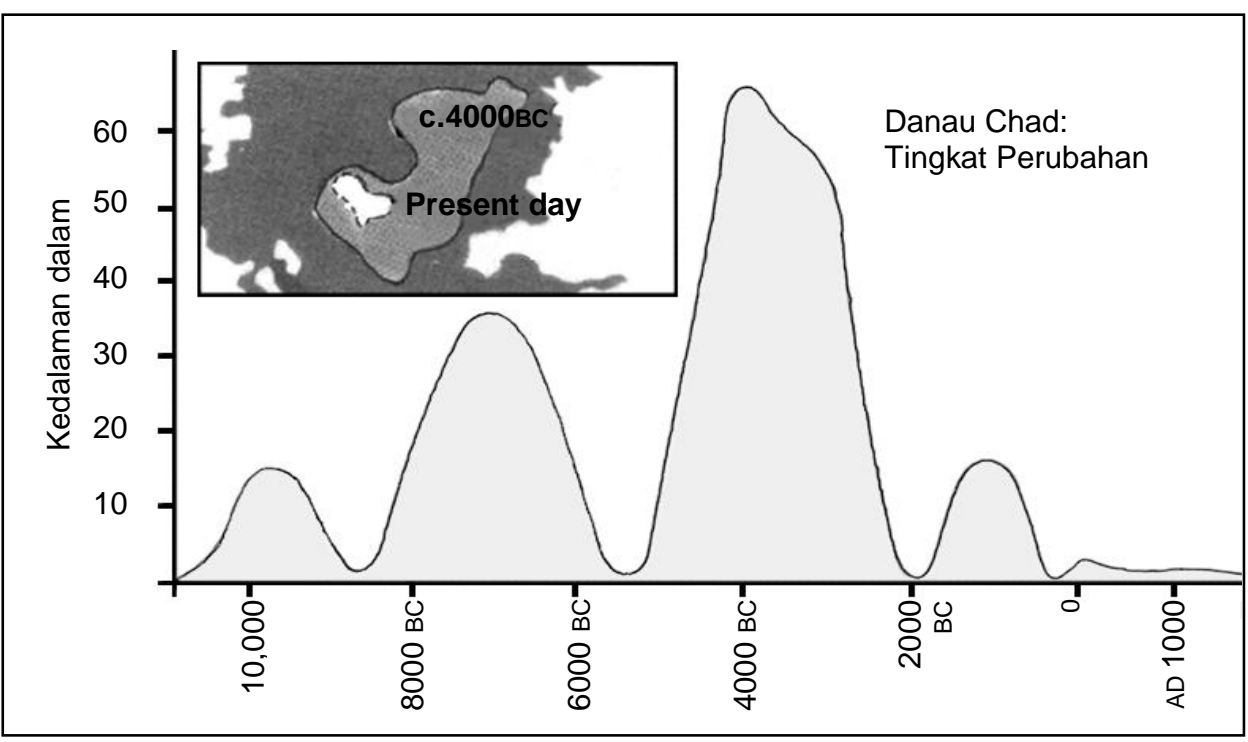

Gambar 1

Gambar 2 menunjukkan seni batu Sahara (gambaran atau kuno yang ditemukan pada dinding-dinding gua) dan perubahan pola hidup binatang buas.

Seni batu sahara dan perubahan pola hidup binatang buas

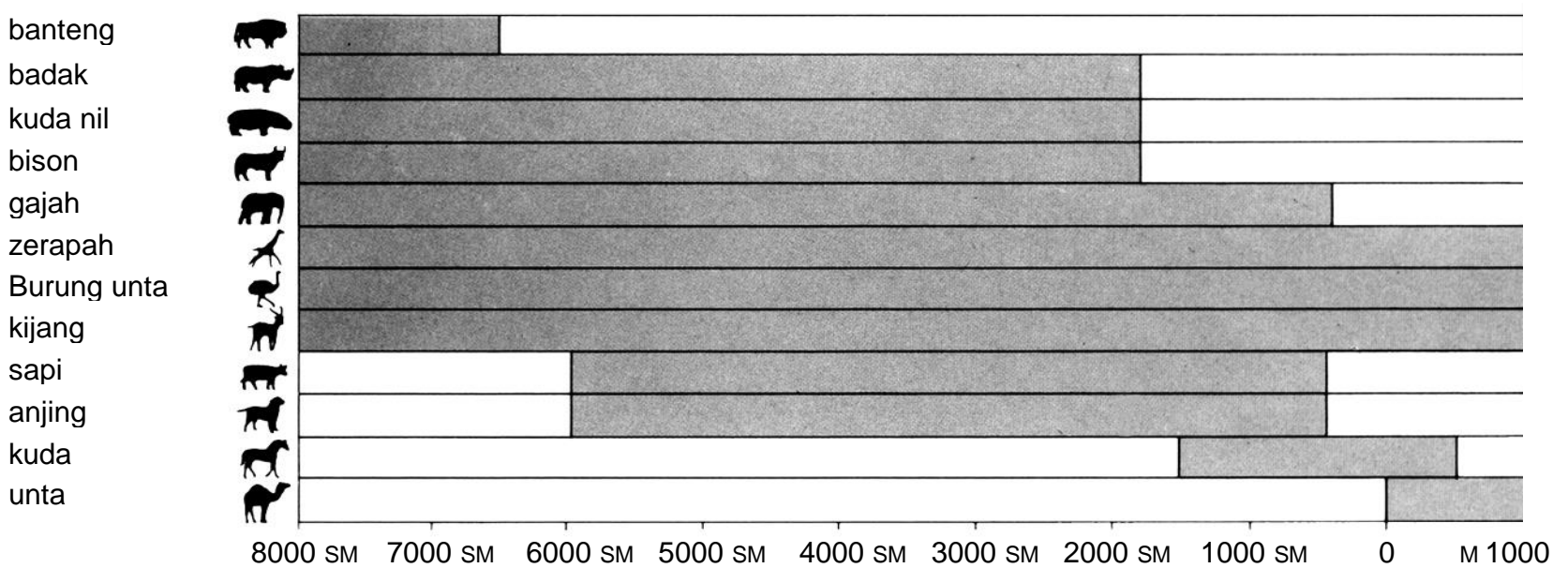

Gambar 2 


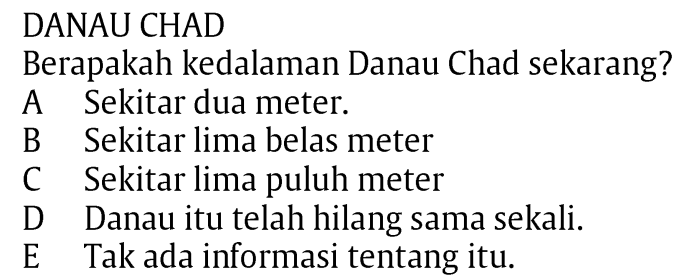

Mengapa penulis memulai grafiknya pada titik tersebut?

\section{R040Q04}

\section{DANAU CHAD}

Gambar 2 didasarkan pada pandangan bahwa:

A binatang-binatang pada seni batu terdapat pada daerah tersebut pada saat digambar.

B para seniman yang menggambar binatang-binatang itu sangat terampil.

C para seniman yang menggambar binatang-binatang itu dapat ber pergian jauh.

D tidak ada usaha menjinakkan binatang-binatang yang digambarkan pada seni batu tersebut.

\section{DANAU CHAD}

\section{R040Q06}

Untuk pertanyaan ini, kamu harus dapat menggabungkan informasi dari gambar 1 dan gambar 2.

Menghilangnya badak, kuda nil, dan bison dari seni batu Sahara terjadi

A pada awal Zaman Es yang terbaru.

B pada pertengahan periode saat Danau Chad berada pada tingkat kedalaman tertinggi.

C setelah dasar Danau Chad menurun selama lebih dari seribu tahun.

D pada permulaan periode kering yang terus menerus.

\section{PEMBAHASAN}

Dari hasil penelitian Balitbang 2011 tentang Trend Kemampuan Literasi Membaca Siswa Indonesia pada PISA ditemukan bahwa kemampuan literasi membaca siswa Indonesia masih di bawah rata-rata kemampuan membaca siswa internasional (Depdiknas, 2011). Kemapuan membaca siswa Indonesia juga baru berada pada level 2 dari 6 level yang ditentukan. Dengan temuan penelitian ini dapat dikaitkan bahwa rendahnya kemampuan membaca pada asesmen internasional PISA terkait dengan jenis kemampuan berpikir tingkat tinggi yang mendominasi soal membaca PISA. Jumlah soal berpikir tingkat tinggi 76\% pada 2000/ 2009, dan 67\% pada tahun 2003/2006.

Kesulitan siswa Indonesia dalam memahami soal PISA juga dapat dipahami dengan adanya temuan pada penelitian ini yaitu karakteristik tiap teks yang relatif panjang yaitu sejumlah 135-630 kata dan variabel grafik/tabel/bagan yang cenderung kompleks. Apalagi jumlah soal pada PISA 2000 dan 2009 sebesar 131. Ketahanan membaca siswa Indonesia yang masih rendah menyebabkan kesulitan yang lebih kompleks lagi. Kesulitan siswa Indonesia dalam membaca juga dapat dikaitkan dengan hasil penelitian ini dari segi penggunaan bahasa pada soal membaca PISA. Hasil analisis menunjukkan bahwa masih terdapat penggunaan campur kode bahasa Indonesia dan bahasa Inggris. Hal ini disebabkan adanya aturan bahwa soal membaca PISA diterima dalam bahasa Inggris dan harus diterjemahkan ke dalam Bahasa Nasional tiap-tiap negara. Soal- soal literasi membaca PISA yang diterjemahkan dari Bahasa Inggris ke dalam Bahasa Indonesia tetap menggunakan latar cerita dan latar budaya Barat dan kurang dipahami siswa. Skemata budaya siswa Indonesia kurang relevan sehingga sulit memahami soal PISA yang sebagain besar bersifat interpretasi, integrasi, refleksi, dan evalausi. Berdasarkan penelitian Matsuda (2005) pemahaman skemata budaya dapat meningkatkan pemahaman inferensial siswa. Latar budaya minat baca yang tinggi pada tempat soal PISA dibuat menyebabkan pilihan teks cenderung dengan jumlah kata yang banyak dan simbol yang rumit. Peta/denah/tabel atau grafik cenderung bersifat kompleks dan berkaitan dengan bagian yang lain. Kecermatan dan kekritisan siswa yang kurang akan menyebabkan rendahnya pemahaman soal PISA.

Dari hasil analisis ditemukan bahwa soal membaca PISA didominasi oleh keterampilan berpikir tingkat tinggi yaitu kemapuan menginterpretasi, mengintegrasikan, merefleksikan, dan mengevaluasi isi teks. Temuan dalam penelitian ini memberikan penjelasan alasan rendahnya kemampuan literasi membaca siswa Indonesia pada PISA mulai tahun 2000-2009. Rendahnya kemampuan literasi membaca PISA selama empat kali pelaksanaan dapat 
dipahami karena soal membaca PISA didominasi keterampilan berpikir tingkat tinggi. Hal ini sejajar dengan hasil penelitian kuantitatif Trend Soal literasi Membaca PISA yang menemukan bahwa kesulitan siswa Indonesia mencakup (a) pertanyaan evaluatif terhadap isi dengan kriteria internal dan memberi alasan, (b) pertanyaani evaluasi berbentuk esai terbatas maupun jawaban singkat, (c) kemampuan mengungkapkan alasan dengan bukti pada isi teks, dan (d) pertanyaan tentang sikap dan strategi penulis

Standar Isi Bahasa Indonesia SMP dan pembelajaran membaca perlu menyesuaikan dengan karakteristik tingkat berpikir tingkat tinggi pada soal membaca PISA sebagi brenchmark internasional anak usia 15 tahun (lulus SMP). Standar Isi Bahasa Indonesia perlu memberikan porsi besar pada keterampilan membaca tingkat tinggi dalam berbagai konteks. Kemampuan merefleksikan dan mengevaluasi isi teks merupakan keterampilan paling sulit dibandingkan keterampilan mengungkapkan kembali informasi. Peningkatan rata-rata kemampuan membaca secara internasional dapat difasilitasi dengan peningkatan pembelajaran kemampuan reflektif. Implementasi pembelajaran keterampilan berpikir tingkat tinggi secara maksimal dan perancangan yang fokus pada Standar Isi bisa memfasilitasi peningkatan literasi membaca pada perspektif internasional.

Di samping itu, pencapaian hasil literasi membaca yang masih di bawah rata-rata kemampuan internasional dimungkinkan karena ketahanan membaca yang masih rendah dari siswa Indonesia. Hal ini dibuktikan dengan hasil penelitian ini yang menuntut ketahanan membaca maksimal untuk dapat mengerjakan soal membaca PISA dengan teks yang panjang-panjang dan mengintegrasikan berbagai teks (multiteks).

\section{SIMPULAN DAN SARAN \\ Simpulan}

Tes literasi membaca PISA memiliki karakteristik berfokus pada kemampuan membaca tingkat tinggi. Jenis kompetensi membaca diklasifikasikan menjadi tiga kelompok yaitu (a) kemampuan mengungkapkan kembali informasi (retrieving Information), (b) mengembangkan interpretasi (developing an interpretation), dan (c) merefleksikan/ mengevaluasi teks. Tes literasi membaca PISA cenderung menggunakan wacana yang panjang dengan jumlah kata 135-600 kata. Kalimat pertanyaan cenderung kompleks. Ragam tes yang digunakan pada soal membaca PISA adalah pilihan ganda, pilihan ganda kompleks, jawaban singkat, esai tertutup, dan esai terbuka. Ragam tes tersebut disajikan bervariasi berdasarkan sebuah teks yang mendahuluinya. Stimulus tes PISA dapat diklasifikasikan menjadi empat kategori, yaitu konteks pendidikan pekerjaan, personal, dan masyarakat. Isi kutipan pada soal membaca PISA dipilih dengan tujuan meningkatkan keterampilan hidup mengakses dan memanfaatkan informasi berupa wacana untuk menjalani kehidupan dalam masyarakat dan menjaga keselamatan/keamanan diri.

\section{Saran}

Berdasarkan temuan di atas disarankan kepada Steikholder di Departemen Pendidikan dan Kebudayaan dan juga Steikholder di LPTK untuk menyosialisasikan karakteristik Tes Pisa dan mewajibkan para guru/dosen untuk mengembangkan tes yang berbasis keterampilan berpikir tingkat tinggi, baik dan bermutu sesuai dengan semangat penilaian abad 21 yang ditunjukkan oleh PISA.

\section{DAFTAR RUJUKAN}

Alderson, J. Charles. 2000. Assessing Reading. Cambridge: Cambridge University Press

Departemen Pendidikan dan Kebudayaan Nasional. 2011. Trend Kemampuan Literasi Membaca pada PISA $2000-2009$. Balitbang: Pusat Penilaian Pendidikan

Hayat, Bahrul. 2006. Kemampuan Dasar Hidup: Prestasi Literasi Membaca Anak Indonesia Usia 15 Tahun di Dunia Internasional. Jakarta: Pusat Penilaian Pendidikan.

Hirai, Debra L. Cook, Irene Borrego dan Emilio Garza, dan Carl T. 2009. Klock. Literacy Strategies for Adolesents: How to Manual for Educator. New York: Routledge Taylor \& Francis Group.

Kalantzis, Mary dan Cope, Bill. 2015. Literacies. Cmbridge: Cambridge University Press.

Krippendorff, Klaus. 1993. Analisis Isi. Jakarta: PT Raja Grafindo Persada.

OECD 2000. Frame Work rogramme International Students Assessment. Paris: OECD.

OECD 2003. Frame Work rogramme International Students Assessment. Paris: OECD.

OECD 2006. Frame Work rogramme International Students Assessment. Paris: OECD.

OECD 2009. Programme International Students Assessmen. Assessment Framework: Key Competencies in Reading, Mathematics, and Science. Paris: OECD.

Sevilla, Consuelo dan Gabriel G. Uriarte. 2001. Pengantar Metode Penelitian. Jakarta: Universitas Indonesia 